New Zealand Journal of Industrial Relations, 17(2): 149-160

\title{
Sex Equality and the Law of Employment
}

\author{
John Dawson*
}

New Zealand statutes appear to ban sex discrimination in employment with the aim of promoting equal opportunities for women. But what vision of 'equality' for women is to be found in the law? Does it only require the 'equal' woman to be treated as if she were a man? Or does the law recognise that women may not be similarly situated to men and so may not be satisfied with identical treatment under gender neutral norms if the outcome of such treatment is to place them at a disadvantage? This paper tries to approach these questions by outlining a feminist analysis of anti-discrimination law in general, then applying it to the broad structure of employment discrimination law in New Zealand.

\section{A feminist analysis of anti-discrimination law}

This paper considers the relevance to our employment law of two contemporary feminist criticisms of the substantive aspects of anti-discrimination law. The first criticism is that the law continues to be based on a male norm. Orthodox equality law requires that women who are similarly situated to men be treated the same as men. This ignores the social fact that men and women are not similarly situated in an unequal society, in which men and women do not, in general, have the same freedom or the same access to resources or the same bargaining power. It also fails to recognise sex discrimination at all in situations which are specific to women. In other words, orthodox law provides a limited and unsatisfactory answer to the question: what is discrimination? The result is that many of the barriers to success or advancement experienced by working women have no legal remedy, even in principle. I will return and develop this argument in a moment.

A second major criticism of anti-discrimination law is linked to the wider feminist critique of the role of law as a major support of the 'public/private' distinction. In the past the law has actively supported and recreated that distinction through legal barriers to women's access to the 'public' zone (e.g., through denial of married women's property rights, lack of the franchise) and through failures to protect women from abuse by men within the so-called 'private' zone (e.g., by failure to criminalise rape or assault within marriage, the absence of adequate divorce or abortion legislation). Now criticism focuses more on the law's failure to recognise the linkage between these two zones of life (e.g., in the law's failure to acknowledge that the division of domestic labour and childcare responsibilities within the family directly impacts on employment opportunities). The law continues to be based on a model of separate spheres rather than one of interdependence.

* Senior Lecturer in Law, University of Otago. Thanks to Selene Mize and a reviewer for comments on earlier drafts. 
My concern is to explore the type of equality for women our law might deliver if it was fully implemented. Many other criticisms might be made of the way in which the law is implemented. These might concern procedural, evidential and attitudinal barriers to bringing successful complaints of discrimination; or highlight the capacity for the law's intentions to be subverted by other economic and social policies followed within a 'free' market order in the era of the shrinking state. For the most part these issues are left for another day.

\section{Difference/dominance}

The criticism that anti-discrimination law continues to be based on the male norm is primarily associated with the work of Catharine Mackinnon, an American law professor and feminist activist, who was the author, with Andrea Dworkin, of the famed Indianapolis antipornography ordinance. Her books, Sexual Harassment of Working Women (1979), Feminism Unmodified (1987) and Towards a Feminist Theory of the State (1989), are core texts of contemporary feminist legal theory.

Mackinnon's (1987) analysis of anti-discrimination law opens with two questions: 'What is a gender question a question of? What is an inequality question a question of?' (p.32). The answer that orthodox American sex discrimination law has given to these questions, she argues, is that gender inequality questions are questions of difference and sameness. The law has been based on the ethical principle that people who are similarly situated should be treated the same, and that people who are differently situated may be treated differently. Aristotle is traditionally quoted as the source of this ethic. Writing in a society in which slavery and prostitution were endemic and women non-citizens, Aristotle ${ }^{1}$ wrote: 'Things that are alike should be treated alike, while things that are unalike should be treated unalike in proportion to their unalikeness.'

Anti-discrimination law in America, based on that proposition, has sought to determine when women are in the same position as men and so should be subject to gender neutral laws; and when women are in a different position to men and so may legitimately be treated differently. The problem with this approach, says Mackinnon (1991), is that it leaves unquestioned "how difference is socially created or defined, who sets the point of reference for sameness, or the comparative empirical approach itself' (p.1287). She asks: 'Since men have defined women as different to the extent that they are female, can women be entitled to equal treatment only to the extent that they are not women?' (Ibid).

The question being asked by the law is: are women like or unlike men? So this approach is based on the male norm and is 'essentially assimilationist' (1991: 1288). It says, 'Be like us and we will treat you like we treat each other' (Ibid). Women have to be the same as men to be treated equally.

This approach has not been totally without advantages for women: e.g., some women have gained access to some professions by this means. But one of its main outcomes has also been to empower men to claim those few benefits to which women have previously been entitled: e.g., by successfully attacking the 'mother principle' formerly followed in child custody cases. This is because the main outcome of this approach in practice has been the

1 In Ethica Nichomachea, bk v3, 1131a, 1131b (W Ross trans 1925), quoted in Mackinnon, C. (1991) 1286. 
recasting of laws in gender-neutral terms. As Mackinnon notes: 'The operative view has been that if classifications that distinguish by sex were eliminated from law, sex equality would be achieved' (1991: 1292).

But gender-neutral classification itself does not ensure equality of outcome in fact. At the University of Otago, for example, when gender-neutral rules have been applied to professorial appointments, men have been appointed to chairs in what was the Home Science School, but very few women have been appointed to chairs in other departments or schools. In recent years, the number of women professors has actually declined. Is this equality? The strict application of gender-neutral rules may even prevent affirmative action programmes, which attempt to redress social inequalities by singling out disadvantaged groups for promotion, for the application of the gender-neutral principle results in affirmative action being seen as an illegitimate form of preference.

An even more powerful criticism of this sameness/difference approach to sex discrimination law, from Mackinnon's perspective, is that it fails to identify those situations in which women are treated unlike men as involving sex discrimination at all: because, 'where the sexes are different ... discrimination as a legal theory does not even come up' (1991: 1288-89). Legal differences based on real distinctions between men and women are not considered unequal treatment at all. So, for example, laws that permit the exclusion of pregnancy costs or childbirth expenses from insurance cover may not be considered discriminatory. As men cannot become pregnant or bear children, men and women are not similarly situated in this regard, so a legal distinction may be considered legitimate (see Geduldig v Aiello, 1974; General Electric v Gilbert, 1976; Dickens, 1991; Fredman, 1992).

So Mackinnon rejects the sameness/difference approach to discrimination law and its implicit foundation on the male norm. For her, equality questions are not questions of sameness and difference. They are not 'ethical' questions at all. They are 'political' questions, of dominance and subordination, power and hierarchy. She advocates an alternative, 'dominance/subordinance' approach. This would focus on situations in which the position of women is generally unlike that of men: e.g., the position of women as victims of sexual violence and pornography. For her, the appropriate focus of sex discrimination law would be to change social situations in which women are rendered victims: to use law as an instrument to achieve structural social change to redress the substantively unequal position of women. She thus imagines a different role for law than the traditional liberal view of it. The traditional liberal approach is to view law as some kind of independent referee: as a neutral enforcer of the ethical principle of equality - an approach that does not require any affirmative action, structural change, group analysis or focus on outcomes.

For Mackinnon, law should not pretend to be neutral, which it never has been with respect to women anyway. It should, if possible, be used by women as a political weapon, in a practice of feminist politics, to force the structural changes required to produce substantive equality and an end to victimisation: e.g., by requiring employers to adopt affirmative action programmes, and by attacking through law the pornography industry. The aim is the end of male dominance in all spheres of social life, equality of power and authority for women and equal distribution of economic benefits.

But such active promotion of the position of women poses a problem for orthodox discrimination law, which is based on the principle of gender neutrality. To quote Mackinnon: 'If differentiation into classifications, in itself, is discrimination, as it is in difference doctrine, the use of law to change group-based social inequalities becomes problematic, even contradictory' (1987: 42). Again: 'If differentiation is discrimination, affirmative action, and any legal change in social inequality is discrimination' (Ibid). So, 
affirmative action programmes for women in employment are attacked or discredited because they treat women differently and so discriminate against individual men; as, in the New Zealand context, affirmative action programmes for Maori are described by some as forms of 'apartheid' or 'special treatment'.

The outcome, argues Mackinnon, can be that orthodox difference/sameness sex discrimination law becomes another means of legitimating the status quo. Attempts to redress social inequalities by law, through singling out disadvantaged groups for special attention, may be classified as discriminatory themselves. The effect of focusing on difference is to perpetuate dominance; and to fail to attack through law those situations in which women are treated most differently to men.

\section{Application to the law of employment}

I now wish to consider in more detail how this type of analysis would apply in the area of employment. I believe its application would cause us to ask of employment discrimination law the following kinds of questions:

First, does the definition of sex discrimination in employment focus exclusively on 'similarly situated' male and female employees, requiring them to be dealt with under gender neutral norms, or can 'discrimination' encompass situations in which men and women are not 'similarly situated' at all? For example, can it extend to cover women-specific injuries in the workplace, or factors in the organisation of work itself that particularly disadvantage many women, because of their different life patterns? Second, are affirmative action programmes for women required, or permitted, or prohibited? And third, does the law address the linkages between the so-called 'public' and 'private' zones of life?

Mackinnon's analysis would lead us to consider insufficient a legal regime limited to the comparison of the positions of 'similarly situated' men and women within the work environment. It would lead us to favour a legal regime that not only permits but forces structural changes in the organisation of work itself, which defines women-specific injuries as sex discrimination, which requires affirmative action, and which seeks to modify factors within the 'private' zone which impact on employment opportunities. At the least, the analysis would encourage us to value legal developments which bring us closer to these goals.

So how does New Zealand law measure up when subject to this form of analysis? There are several statutes in force in New Zealand concerning sex discrimination law in employment: e.g., the Equal Pay Act 1972, the Human Rights Commission Act 1977, the Parental Leave and Employment Protection Act 1987 and the State Sector Act 1988. There are provisions concerning access to personal grievance procedures for discrimination or sexual harassment in the Employment Contracts Act 1991. The definition of rape in the Crimes Act 1961 is relevant; plus, of course, the Employment Equity Act 1990 which blazed like a comet across our legal sky.

\section{The definition of discrimination}

The Human Rights Commission Act bans discrimination in employment and entry into partnerships 'by reason of' sex or marital status. Section 15(1) provides: 


\begin{abstract}
'It shall be unlawful for any person who is an employer, or any person acting or purporting to act on behalf of any person who is an employer, -

(a) To refuse or omit to employ any person on work of any description which is available and for which that person is qualified; or

(b) To refuse or omit to offer or afford any person the same terms of employment, conditions of work, fringe benefits, and opportunities for training, promotion, and transfer as are made available for persons of the same or substantially similar qualifications employed in the same or substantially similar circumstances on work of that description; or

(c) To dismiss any person, or subject any person to any detriment, in circumstances in which other persons employed by that employer on work of that description are not or would not be dismissed or are not or would not be subjected to such detriment -

by reason of the sex, marital status, or religious or ethical belief of that person.
\end{abstract}

The Employment Contracts Act also designates discrimination in employment a form of personal grievance, with 'discrimination' defined in almost identical terms. The aggrieved employee must choose whether to proceed through the personal grievance procedures or by complaint to the Human Rights Commission (Employment Contracts Act ss27, 28(1), 39).

The rulings of the Equal Opportunities Tribunal have now established that decisions are reached 'by reason of' a prohibited ground when that ground forms a 'substantial and operative factor' in the decision (Eric Sides Motors, 1981); and decisions are reached 'by reason of sex' when 'sex is for no legitimate reason a substantial factor in the discrimination' or where the decision would not have been reached 'but for' the victim's sex $(H v E, 1985)$. The Tribunal has adopted the 'sex-plus' jurisprudence followed in Australia, Canada and the United States. Thus, 'so long as gender provides a basis for differentiation it matters not that further differentiation on another basis is made' ( $H v E$, quoting Zarankin $v$ Wessex Inn, 1984). Applying this holding in $H v E$, the Tribunal found sexual harassment to be a form of discrimination prohibited by the Human Rights Commission Act. It matters not that all women employees are not similarly harassed, nor that only women attractive to the employer are harassed, sex is still a substantial factor in any case of sexual harassment of a woman by a heterosexual male. The disingenuous defence, that a woman is harassed by reason of her attractiveness, not her sex, is not available! This provides a partial answer to the question concerning the scope of 'discrimination' and women-specific injuries. No doubt women are more frequently the victims of sexual harassment. In this respect male and female employees are not 'similarly situated'. But our law does recognise discrimination in this situation.

The law's ban on the unfavourable treatment in employment of pregnant women provides another example. Applying the sex-plus approach, a pregnant woman's membership of the female sex is plainly a 'substantial factor' in such treatment, even though she suffers a detriment because she is both a woman and pregnant. So such treatment may be considered discriminatory under s15, especially if we follow the 'liberal and enabling' ( $H v E, \mathrm{p} .348)$ or 'remedial' (Parr v BCNZ, 1987: 95,567) approach to interpretation favoured by the Tribunal. That a man can never be in a similar situation to a pregnant woman is irrelevant. The position is put beyond doubt with regard to dismissal by s49(1) of the Parental Leave and Employment Protection Act which bans dismissal 'by reason of' pregnancy, state of health during pregnancy, or the decision to take parental leave or to adopt a child.

So, while the definition of discrimination in $\mathrm{s} 15(1)$ appears to focus primarily on comparisons between individuals having 'the same or substantially similar qualifications 
employed in substantially similar circumstances' the interpretation of discrimination adopted by the Tribunal does permit the provision of remedies in some situations where women are treated differently to men. Not all treatment based on differences is considered legitimate.

\section{Indirect discrimination}

But there are clearly limits to how far the statutory definition of discrimination may be extended. This becomes apparent when we consider the likely legal response to complaints of 'indirect' discrimination; i.e., complaints concerning requirements or conditions of work which appear on their face to apply equally to both sexes but which in fact disproportionately disadvantage many women because of their different life patterns: e.g., conditions of employment requiring extensive travel, or early evening shifts, or membership in sports or service clubs to attract clients.

What would be the response, for example, to a complaint of discrimination relating to the requirement in some occupations that employees work long hours, without job-sharing arrangements or childcare facilities being provided? Imagine an executive position is advertised which requires of the employee 'one hundred percent commitment' and a sixty hour week. Two women with young children jointly apply for the position on a job-sharing basis. They both have superior qualifications to all other applicants. They are not employed. Have they been discriminated against? Has the employer refused to employ them 'by reason of their sex', contrary to s15(1)(a)? Or have they been refused by reason of their failure to meet the specified conditions of employment which were offered on a formally equal basis to members of both sexes? Can the law recognise discrimination in situations where formally 'equal' conditions of employment impact differently on the sexes? Would the women's life patterns, not the offer of inflexible working conditions, be considered the cause of their failure to gain employment?

Here we must consider the relevance of s27 of the Human Rights Commission Act, prohibiting 'discrimination by subterfuge'. This provision is treated by the Equal Opportunities Tribunal in Proceedings Commissioner v Air New Zealand (1989). The Tribunal's analysis of the requirements of $s 27$ recognises the expansive and 'progressive' approach to 'indirect' discrimination taken in the United States and England and accepts that an omission to take action to remedy past discriminatory practices can constitute 'discrimination' under the Act. S27 was found breached by an apparently 'neutral' condition of employment which had the effect of perpetuating a prior pattern of discrimination. To establish a breach of $s 27$ the complainant must show that a requirement or condition of employment exists which is not apparently in contravention of the Act; that this has the effect of giving preference to a male (or males); and that the preference occurs in a situation where the giving of preference to a male would be unlawful. It then falls on the defendant to try to show there is a 'good reason' for the imposition of the requirement or condition and to show that its imposition is not a subterfuge to avoid complying with the law. But the case law provides little guidance as to which 'good reasons' will be acceptable. Will marginal contributions to business efficiency or profitability be considered sufficient? (See Rainey $v$ Greater Glasgow Health Board, 1987; Dickens, 1991; Fredman, 1992).

Returning to the earlier example, if the employer can show that clients prefer to deal with a full-time employee rather than the partners in a job-sharing arrangement will that justify the omission to employ the two women? Perhaps not, if the Tribunal continues to take 
a remedial and expansive view of the Act's prohibition of indirect discrimination and discrimination by omission. Alternatively, the Tribunal may take a more restrictive approach based on the language of s15. S15(1)(b) suggests that offering the 'same' conditions of work to both sexes is all that is necessary. Comparisons are to be made between persons employed in 'substantially similar circumstances'. But this begs the question, of course, as to whether identical conditions are 'the same' for differently situated employees.

The differential impact on some women of identical working conditions to men may not be considered the responsibility of employers, or discrimination. It may be considered the result of general social patterns beyond employers' control or 'lifestyle choices' made by the women themselves; though this may ignore the extent to which past employment practices have themselves shaped those patterns and 'choices'. Certainly there is little evidence in the reported decisions of the Tribunal that complaints concerning the structure of the 'normal' working week will be successful. To this extent women are bound to male work norms, although formally gender-neutral standards are applied. Social factors which mean women may not seek to work in identical conditions to men are not recognised in this model.

\section{Affirmative action}

There is nothing in the Human Rights Commission Act or elsewhere which requires employers to adopt affirmative action programmes for women. Indeed, under s15's definition of discrimination these may be considered to discriminate against men, if they result in employers refusing to employ or promote men 'by reason of' their sex. This is spelled out in Parr's case where it was said it would be discriminatory to prefer a man over a more qualified woman for the purposes of achieving a better balance of the sexes in a particular area of work. The Tribunal found: 'The Act does not permit the selection of applicants in order to achieve a balance of the sexes. Such a concept is contrary to the letter and spirit of the Act' (Parr v BCNZ, 1987: 95,572). This would prevent the use of 'strong' affirmative action programmes which permit the appointment of a woman over a better qualified male applicant. Where the applicants are equally qualified, the choice of either would always be open, so to deliberately choose the woman may be considered legitimate. This may save 'weak' programmes, or the 'plus factor' approach, though this is debateable.

A specific exception is provided by $s 28$ which permits the Commission to approve affirmative action programmes for women which are submitted to it. Nothing requires employers to develop programmes or to submit them. The development of 'equal employment opportunities programmes' in government departments and education services is legally required by ss58 and 77D State Sector Act. Management must publish the programme, ensure compliance and report publicly on implementation. This was also the focus of the second aspect of the Employment Equity Act 1990. It would have required all major employers in the state and the private sectors (Backgrounder, 1989) 'to develop equal employment opportunities programmes aimed at the identification and elimination of all aspects of policies, procedures and other institutional barriers that cause or perpetuate inequality'. Monitoring procedures were established to scrutinise employers' adherence. Flexible working hours, job-sharing, seniority for part-time workers, recognition of different skills or qualifications - significant changes to the structure of working life in all major areas of employment may possibly have been stimulated by the implementation of such programmes. This requirement also is now repealed, although the provisions in the State Sector Act remain (see Tremaine, 1991). 


\section{Rates of pay}

With regard to pay, the law is still substantially based on a model involving the comparison of 'similarly situated' men and women. The effect of the Equal Pay Act is to require individuals working in the same or substantially similar jobs to be paid the same regardless of their sex. It prohibits differential pay rates between 'similarly situated' men and women (ss6(8),7) and bans sex-based classification of work tasks (s3(3)). But the Act has not redressed pay differentials between occupational classes, i.e., it has not prevented occupations dominated by women (e.g., nursing) receiving lower rates of pay than occupations dominated by men (e.g., policing). That claims across occupational classes (what we now call pay equity claims) could not succeed under the Equal Pay Act was made clear by the Arbitration Court in 1986 when it held it did not have the jurisdiction to hear such a claim (NZ Clerical Administrative etc IAOW v Farmers Trading Co Ltd and others, 1986).

This, of course, was a key objective behind the Employment Equity Act 1990. That statute would have permitted large-scale comparisons to be made across occupational categories. It could have led progressively to significant changes in rates of pay throughout the workforce. It was explicitly aimed at achieving the type of structural changes a feminist approach would favour, hence, perhaps, the strength of the successful opposition to it.

Now the implementation of the Equal Pay Act itself may be hindered by the new employment environment in the wake of the Employment Contracts Act. It may be more difficult to measure 'equal pay' between work performed by men and women, for two reasons. First, employment contracts will become less public. The rates of pay established by national awards were in the public domain, but much less information will be available concerning wages or salaries set by individual (and even small collective) employment contracts. Second, widely varying rewards may become established for similar work, in different regions, firms or industries, making it much more difficult to measure 'equal pay'. In a situation of greater wage pluralism there will clearly be increased difficulties in establishing that the wage differential between a male employee and female employee is 'based on the sex of the employees' (Equal Pay Act, s2). So a further difficulty is added to the formidable problems in establishing what determines rates of pay (see also Szyszczak, 1985).

\section{Women-specific injuries}

During the 1980s the law has moved to recognise women-specific workplace injuries as sex discrimination. Sexual harassment was recognised by the Equal Opportunities Tribunal as a form of sex discrimination under the Human Rights Commission Act, although it is not mentioned in the legislation. The Labour Relations Act 1987 then recognised sexual harassment as a form of personal grievance for unionised workers (see Boast, 1988). The Employment Contracts Act 1991 has extended this cover to all workers (ss27,29). Every employment contract must have (or is deemed to have) an effective procedure for the resolution of such grievances (s32). In considering a complaint of sexual harassment no account is to be taken of the victim's sexual experience or reputation (s35). Employers are responsible for taking steps to prevent sexual harassment by other workers, clients or customers following complaints (s36). Employees who sexually harass co-workers may be dismissed, provided correct dismissal procedures are followed (see Coleman, 1988). 
The Rape Law Reform Act 1985 also created a new offence of inducing sexual connection by coercion, which attracts the same level of penalty as rape. The definition of the offence expressly recognises that a woman may be induced to consent by abuse of occupational or employment authority. Section 129(1) of the Crimes Act now reads:

Everyone is liable to imprisonment for a term not exceeding 14 years who has sexual connection with another person knowing that the other person has been induced to consent to sexual connection by:

(c) An express or implied threat ... to make improper use, to the detriment of the other person, of any power or authority arising out of any occupational or vocational position held by the person ... or any commercial relationship between [them].

Previously, this behaviour would not have been considered criminal at all. These are surely significant advances in the substance of the law, though there are barriers to enforcement still to be overcome (see Hicks, 1988; Dickens, 1991).

\section{Public/private linkage}

The area in which the law has moved the least is in recognition of the linkages between the 'public' and the 'private' spheres. Dickens' (1991) criticism of the British legislation may also be made of our own: it 'fails to acknowledge the two-way link between women's domestic and wage labour roles and displays little appreciation of the process of gendering' (p.294). So how could the law more adequately recognise this interdependence? For while there can be little doubt that greater male participation in domestic labour and childcaring is a precondition of employment opportunity for women, attempts to coerce men through law to change their behaviour within the domestic sphere seem unlikely to succeed. We do not have a Male Domestic Labour Act; and perhaps we should not. Perhaps the home should be a 'private' place, beyond state regulation, for some purposes.

So while attempts at coercive intervention may be inappropriate, we are not precluded from using the law to facilitate or encourage changes in domestic roles. Legislation can be used to ease the burden of childcare. It can permit both parents to take parental leave. We could even legislate for an optional six-hour working day, to facilitate more equal responsibilities. But while some parental leave rights have been established and minimal state subsidisation or tax relief provided for childcare costs, we are now seeing these latter advances rolled back. There have been no attempts to require employers to provide childcare facilities.

The Parental Leave and Employment Protection Act provides for statutory, unpaid parental leave entitlements and limited job security for longer-term employees who take leave, plus some ancillary benefits. Both parents may take leave, including adopting parents, up to 54 weeks between them. There is a further entitlement to ten days special leave without pay for reasons connected with the pregnancy. Most health costs associated with pregnancy and childbirth continue to be borne by the public health system. But there is no requirement that employers should pay their employees during parental leave or any part of it, nor is a social welfare benefit available for such purposes. Because, for the most part, it is women who exercise statutory parental leave rights, the absence of remuneration continues to place them in a position of economic dependence. The New Zealand situation may be compared with 
that in Sweden where an extensive system of state-funded benefits exists to provide a proportion of the employee's usual remuneration, both during initial parental leave and during periods of later leave taken to care for an unwell child (see Widenberg,1991).

It is hard to imagine government sponsorship of such developments in the current political climate. Opposing arguments based on cost, freedom of contract and the defence of economic efficiency seem likely to prevail. The model of separate spheres is set to continue, with discrimination viewed as 'a problem experienced by individual women within selected areas of their lives' (Dickens, 1991: 293).

\section{Conclusion}

How, then, should we answer the question posed at the start of this paper? What vision of equality for women is to be found in New Zealand law? We have seen that our law does not provide a clear vision of the 'equal' woman employee at all, but a plausible composite portrait would be of an individual who has made 'private' arrangements for childcare and domestic labour responsibilities. In general, women are to be granted access on an identical basis to men to identical conditions of work. They are to be free of overt sexual harassment and sexual coercion in the work environment. They are not to suffer detriment due to pregnancy and are entitled, with their partners, to unpaid parental leave and to return to their jobs. But the law gives little attention to working women's other concerns, about sharing domestic labour with unwilling men, about the structure of the orthodox working week, about poor wages in female-dominated occupations and about the reluctance of the 'captains' of industry to actively promote women's opportunities. These may be important concerns of working women. They are not at present legal concerns.

The sex discrimination statutes governing employment passed in this country in the 1970s, while they were advances which helped create a political climate in which further reforms such as the Employment Equity Act were possible, are now vulnerable to feminist criticism. They are largely based on a model involving gender-neutral comparisons between individuals, though creative interpretation by the Equal Opportunities Tribunal of the meaning of discrimination has rendered unlawful some practices of which women are the main victims. But the scope of women-specific injuries which will be considered unlawful is limited and may not extend to many forms of 'indirect' discrimination. In the 1980s we have seen a distinct move, led by the women members of the fourth Labour Government, to adopt some public policies aimed at achieving structural changes, such as alterations in the organisation of work itself, class-based wage comparisons and subsidisation of childcare. Now, in the 1990s we are starting to see some of those developments rolled back as a feminist perspective no longer influences government policy. Rather than the law moving forward to explicitly recognise the linkages between the 'public' and 'private' zones, we see instead, in the Employment Contracts Act, the beginning of a reconceptualisation of the zone of employment as itself a 'private' zone, in which arrangements will be made between 'individuals'. This augurs badly for feminists who seek to rely on inequalities in outcomes between groups of men and women as a justification for legal reform.

It also challenges the idea that progress towards feminist legal objectives is an inevitable, evolutionary process, in which the law simply comes to reflect underlying social movements. The law can also frustrate and even reverse social movements. The legal progress of the last century, from the Married Women's Property Act 1884, through electoral 
reform, entry to the professions, equal pay, the Human Rights Commission Act, to pay equity legislation, may have looked unstoppable, only requiring time for more progress to be achieved. But the 1990 s demonstrate that not only time but action is required to advance feminist legal objectives, and to defend those already achieved.

\section{References}

Boast, R. (1988), The Sexual Harassment Provisions of the Labour Relations Act, New Zealand Journal of Industrial Relations, 13: 285-289.

Coleman, M. (1988), A Trade Union Perspective on Sexual Harassment, New Zealand Journal of Industrial Relations, 13: 295-299.

Dickens, L. (1991), Road Blocks on the Road to Equality: the Failure of Sex Discrimination Legislation in Britain, Melbourne University Law Review, 18: 277-297.

Fredman, S. (1992), European Community Discrimination Law: a Critique, Industrial Law Journal, 21: 119-134.

Hicks, C. (1988), Does the Sexual Harassment Procedure Work?, New Zealand Journal of Industrial Relations, 13: 291-293.

Mackinnon, C. (1979), Sexual Harassment of Working Women, New Haven, Yale UP.

Mackinnon, C. (1987), Feminism Unmodified, Cambridge, Miass, Harvard UP.

Mackinnon, C. (1989), Towards a Feminist Theory of the State, Cambridge, Mass, Harvard UP.

Mackinnon, C. (1991), Reflections on Sex Equality under the Law, Yale Law Journal, 100: 1281-1328.

Minister of Women's Affairs (8 November 1989), Backgrounder on Employment Equity Policy.

Szyszczak, E. (1985), Pay Inequalities and Equal Value Claims, Modern Law Review, 48: 139-157.

Tremaine, M. (1991), Equal Employment Opportunity and State Sector Reform, In J. Boston et al. (eds), Reshaping the State, Auckland, Oxford.

Widenberg, K. (1991), Reforms for Women - on Male Terms - the Example of the Swedish Legislation on Parental Leave, International Journal of the Sociology of Law, 19: 27-44. 


\section{John Dawson}

\section{List of cases}

Geduldig v Aiello (1974) 417 US 484

General Electric v Gilbert (1976) 429 US 125

$H \vee E(1985) 5$ NZAR 333

Human Rights Commission v Eric Sides Motors (1981) 2 NZAR 447

NZ Clerical Administrative etc IAOW v Farmers Trading Co Ltd and others [1986] ACJ 203

Parr v Broadcasting Corporation of New Zealand (1987) 1 NZELC 95,560

Proceedings Commissioner v Air New Zealand (1989) 2 NZELC 96,614

Rainey v Greater Glasgow Health Board [1987] AC 224

Zarankin v Wessex Inn (1984) 5 Canadian Human Rights Reporter 387 